Toplum Bilimleri Dergisi - Journal of Social Sciences

ISSN: 1306-7877 e-ISSN: 2147-5644

Lise ve İlkokul Öğretmenlerinin Duygusal Emek Gösterim Düzeyleri Emotional Labor Display Levels of High School Teachers and Classroom Teachers Ahmet GÖÇ

Maarif Müfettişi, İl Mili Eğitim Müdürlüğü

Çanakkale, Türkiye

Inpector of Education, Provincial Directorete of National Education

Çanakkale, Turkey

ahmetgoc35@gmail.com

https://orcid.org/0000-0002-6797-9781

Osman ÇEKIÇ

Doç.Dr., Çanakkale Onsekiz Mart Üniversitesi,

Doç.Dr., Çanakkale Onsekiz Mart Üniversitesi, Eğitim Fakültesi

Çanakkale, Türkiye

Assoc. Prof. Dr., Çanakkale Onsekiz Mart University, Faculty of Education

Çanakkale, Turkey

osmancekıc@gmail.com

https://orcid.org/0000-0002-3600-2855

Makale Bilgisi / Article Information

http://dx.doi.org/10.29238/tbd.2007.49312

Makale Türü / ArticleTypes: Araştırma Makalesi / Research Article

Geliş Tarihi / The Article Arrival Date: 09.02.2021

Yayımlanma Tarihi / Publication Date: 25 Haziran / June 2021

Yayımlanma Sezonu / Publication Season: Haziran / June 2021

Cilt / Volume: 30

Sayfa / Pages: 231-249

Copyright (C) Published by Toplum Bilimleri Dergisi - Journal of Social Sciences.

All rights reserved www.toplumbilimleri.com 


\title{
Lise ve İlkokul Öğretmenlerinin Duygusal Emek Gösterim Düzeyleri
}

Özet: Bu araştırmanın temel amacı İlkokul ve lisede görev yapan öğretmenlerin duygusal emek gösterim düzeyleri arasında fark olup olmadığının araştırılmasıdır. Katılımcılar Çanakkale ili Gelibolu ilçesinde bulunan ilkokul ve liselerde görev yapan 102 sınıf öğretmeni ve 135 lise öğretmeninden oluşmaktadır. Araștırmaya konu olan, birey ya da nesneler kendi koşulları içinde, olduğu gibi tanımlamaya çalışıldığından nicel tarama modeli kullanılmıştır. Veriler, Diefendorff (2005) tarafından geliştirilen ve Basım ile Begenirbaş (2012) tarafından Türkçe'ye uyarlanan Duygusal Emek Ölçeği ile toplanmıştır. Verilerin analizinde betimsel istatistikler ve MANOVA analizi kullanılmıştır. Öğretmenlerin, en çok doğal duygular alt boyutunda duygusal emek gösteriminde bulundukları görülmüştür. Yüzeysel rol yapma ile derin rol yapma alt boyutlarında ilkokul öğretmenlerinin lise öğretmenlerine göre daha düşük, doğal duygular alt boyutunda ise ilkokul öğretmenlerinin lise öğretmenlerinde göre daha fazla duygusal emek gösteriminde bulundukları görülmüştür. Cinsiyet açısından değerlendirildiğinde ise derin rol yapma alt boyutunda erkek öğretmenlerin kadın öğretmenlerden daha fazla duygusal emek gösteriminde bulundukları bulgularına ulaşılmıştır. Ayrıca bulgulara ilişkin önerilere yer verilmiştir.

Anahtar Kelimeler: Duygusal emek, Yüzeysel yol yapma, Derin rol yapma, Doğal duygular, Öğretmenler.

\section{Emotional Labor Display Levels of High School Teachers and Classroom Teachers}

\begin{abstract}
The main purpose of this study is to determine whether there is a difference between the emotional labor display levels of teachers working in primary and high schools. Respondents of the study consisted of a total of 237 teachers, including 102 elementary school teachers and 135 high-school teachers, working in primary and high schools in the Gallipoli district of Çanakkale. Since the subjects of the study and their emotional labor levels were evaluated in their natural environments through a scale, a quantitative descriptive survey model was utilized in the study. The data was collected using Emotional Labor Scale which was developed by Diefendorff (2005) and adapted to Turkish by Basım and Begenirbaş (2012). The data was analyzed using descriptive statistics and MANOVA. The study results showed that teachers demonstrate emotional labor in the form of superficial role-playing, deep role-playing, and natural feelings, from low to high correspondingly. In the sub-dimensions of superficial acting and deep acting, primary school teachers showed less emotional labor than high school teachers; whereas in the sub-dimension of natural emotions, primary school teachers showed more emotional labor than high school teachers. In terms of gender differences; it was found that males show more emotional labor than female teachers in deep role-playing sub-dimension. Comments according to the findings were also included in the study.
\end{abstract}

Keywords: Emotional labor, Superficial acting, Deep acting, Natural emotions, Teachers.

\section{GíRiş}

Örgütler, toplumsal gereksinimleri karşılamak için oluşturulurlar. Toplum da örgütlerden sorunlarına kalıcı çözümler bulmalarını bekler. Örgüt, toplumun beklentilerine cevap verebildiği ölçüde etkili etkili olur ve varlığını devam ettirir. Örgütün varlığı, birçok bileşene bağlıdır ve işgören yeterliliği de bu bileşenlerden biridir. Örgüt, iş görenlerinden müşterilerinin beklentilerine cevap verebilecek davranışlar göstermeleri bekler. Özel yaşamlarındaki sorunları örgütlerine taşınması istenmez. Hochschild, 
duygusal emeği "iş görenlerin işlerini yaparken müşterinde olumlu izler uyandırmak için duygularını denetleyerek, önceden belirlenmiş kalıplar halinde müşteriye sunmaları" olarak tanımlamaktadır (Hochschild, 1983:7 akt. Savaş, 2012:3). Ashforth ve Humphrey ise "müşteriye hizmet süreçlerinde, örgüt tarafından arzu edilen duyguların yansıtılması" olarak tanımlamaktadırlar (Ashforth ve Humphrey, 1993: 88. akt. Öz, 2007: 6). Morris ve Feldman ise "kişiler arası iş süreçlerinde örgütün arzu ettiği duyguları (davranış kuralları) yansıtmada gerekli olan çaba, planlama ve kontrol" olduğunu söylerler (Ashforth ve Humphrey, 1996: 987. akt. Öz, 2007: 8). Yine bu konuda önde gelen yazarlardan Grandey de "çalışanların örgütün taleplerini yerine getirmek için duygularını ayarlama sürecinde gösterdikleri çaba" olarak tanımlamaktadır (Grandey, 1999: 8. akt. Öz, 2007: 11).

Hochschild, yaptığı çalışmalar sonucunda duygusal emeği, "yüzeysel rol yapma" ile "derin rol yapma" şeklinde iki boyut olduğunu vurgulamıştır (Öz, 2007; Özgen, 2010). Ashforth ve Humphrey ise iş görenlerin her zaman duygularını, müşterinin istediği veya beklediği duygulara dönüştürmek durumunda olmayıp bazen gerçekten gösterdikleri şekilde hissettiklerini, duygularını benzeştirmek için uğraşmak zorunda kalmadıklarını, sergilemiş oldukları davranışlarının o an hissettikleri duygular ile aynı olduğunu ifade etmişler ve buna da doğal duygular adını vermişlerdir. Ashforth ve Humphrey'in katkıları ile Hochschild'in duygusal emek tanımlamasına "derin duygular" boyutunu eklemişlerdir (Öz, 2007; Özgen, 2010; Basım ve Begenirbaş, 2012; Akbıyık, 2013).

Morris ve Feldman ise duygusal emeği, "duyguların gösterim sıklı̆̆ı", "gösterim kurallarına verilen önem/dikkat", "duygu çeşitliliği" ve "duygusal uyumsuzluk" olarak boyutlandırmışlardır (Öz, 2007; Özgen, 2010). Kruml ve Geddes ise duygusal emeğin "duygusal çaba" ve "duygusal uyumsuzluk" olmak üzere iki boyutu olduğunu ifade etmişlerdir (Özgen, 2010). Grandey ise Hochschild, Ashforth ve Humprey, Morris ve Feldman'ın çalışmalarını esas almak kaydı ile duygusal emeği kavramsallaştırmaya çalışmış ve hepsinin ortak noktasının iş görenlerin duygusal gösterimlerini, ifadelerini işinde ve iş yerinde düzenleyebileceği olduğuna vurgu yapmış ve "duyguların ve ifadelerin örgütsel amaçlar için düzenleme süreci” olarak tanımlamıştır (Özden, 2010).

$\mathrm{Bu}$ çalışmada duygusal emek Hochschild ile Ashforth ve Humprey'in 'yüzeysel rol yapma', 'derin rol yapma' ve 'doğal duygular" şeklinde açıklamış olduğu üç boyut olarak ele alınmıştır.

Yüzeysel rol yapma, çalışanlardan gerçek hisleri yerine örgütlerin kendilerinden bekledikleri duyguları sergilemesini, bir anlamda sahte duygular ile hareket etmeleri, gerçek hislerini müşteriye yansıtmaması olarak tanımlanır. Gerçek duygular saklanır, olması gereken duygular rol olarak sergilenir (Akbıyık, 2013; Basım ve Begenirbaş, 2012; Begenirbaş ve Meydan, 2012; Çukur, 2009; Kaya, 2009; Köksel, 2009; Öz, 2007; Özgen, 2010).

Derin rol yapmaya gelince çalışanın gerçek hisleri ile kendisinden beklenen davranışlar ile uyumlu hale getirme halidir, gayretidir. Göstermek zorunda olduğu duyguyu bizzat yaşamasıdır (Akbıyık, 2013; Basım ve Begenirbaş, 2012; Begenirbaş ve Meydan, 2012; Çukur, 2009; Kaya, 2009; Köksel, 2009; Öz, 2007; Özgen, 2010).

Doğal duygular ise çalışanın yüzeysel veya derin rol yapma davranışı yerine gerçekten hissederek davranabilmesi ile ilgilidir. İşgörenin davranışına o anki duygusu hakimdir. Ne müşterinin hissettiği gibi hissetmeye çalışıp derin rol yapma içindedir ne de müşteriyi aldatmaya yönelik yüzeysel rol yapma davranışında bulunur. Müşterinin gözlemlemiş olduğu ya da maruz kaldığı iş gören davranışına, iş görenin doğal duyguları hakimdir (Akbıyık, 2013; Basım ve Begenirbaş, 2012; Begenirbaş ve Meydan, 2012; Çukur, 2009; Kaya, 2009; Köksel, 2009; Öz, 2007; Özgen, 2010). Hochschild ise doğal duygular boyutunu, işgörenin olaylar karşısında gerçek hisleri olduğundan bir emek sarf etmediği için duygusal emeğin bir boyutu olmadığını düşünür (Hochschild, 2003).

İnsanlar, yaptıkları işlerine sadece fiziksel emeklerini katmazlar. Çalışma sırasında duyguları ile de hareket ettiklerinden, duygularının emeklerine etkileri söz konusudur.

Toplum Bilimleri Dergisi, Yıl: 15, Sayı: 30, Haziran 2021, s. 231-249 
Duyguların olumlu etkileri olabileceği gibi olumsuz etkileri de olabilir. Verimlilik için iş görenlerin duygusal emeğinin pozitif yönde olması beklenir. Okulların hedeflerine ulaşmasında öğretmen davranışlarının ötesinde katkılara ihtiyaç vardır. Eğitim faaliyetlerinin etkililiğinde öğretmen katkıları hiç şüphesiz çok önemlidir. Duygusal emek, fiziksel iletişimin olduğu yerde bedensel davranışlar olarak gözlenmesinin yanında jest, mimik, ses tonu ve bireyin sesine yansımaktadır. Kişinin yapıp ettikleriyle birlikte sesine de etkileri olan duygusal emek, karşıdaki kişi üzerinde etkili olacaktır.

Her geçen gün hizmet sektöründeki örgütler, toplum içindeki ağırlı̆̆ını artmaktadır. Müşteri memnuniyeti, hizmetin kalitesi ile doğru orantılıdır. Hizmetin kalitesi, satılan malın kalitesinin yanında mal satışı sırasında iş görenin müşteri ile kurduğu pozitif yönlü ilişki ile de ilgilidir. İş görenin hizmet sunumu, o anki duygularının etkisindedir. Hizmet sunum sırasında duyguları pozitif olan mutlu iş görenler, hizmetten yararlananlara iyi davranırlar. Patronlar veya yöneticiler, çalışanlarının o anki duygusal durumları ne olursa olsun müşteriye mutlaka iyi davranmaları gerektiğine yönelik bir anlayışa sahiptirler. İş görenlerinin böyle davranmaları halinde örgüte katkı sağlayacağını, etkililiği ve verimliliğin artacağını düşünürler. Yakın zamanda, dünyada ve Türkiye'de duygusal emek ile ilgili çalışmalar, farklı hizmet sektörlerinde araştırma konusu olmaya başlamıştır. Ancak, yapılan araştırmalara bakıldığında daha çok ticari kuruluşlarda çalışma alanı bulduğu görülmektedir. Eğitim alanında geldiğinde ise bu çalışmalar yok denecek kadar azdır. Farklı yazarların Türkçe'ye çevrilmiş ölçme araçları söz konusudur ve bu ölçme araçlarıyla araştırmalar yürütülmektedir (Çukur, 2009; Basım ve Begenirbaş, 2012, Köksel, 2009; Öz, 2007). Bunlar arasında Basım ve Begenirbaş'ın (2012) Türkçe'ye kazandırdığı 13 maddelik duygusal emek ölçeği en çok yararlanılanlardan birisi olmuştur.

Basım ve Begenirbaş'ın (2012) Türkçe'ye çevrilerek geçerlik ve güvenirlik testinden geçirdiği "duygusal emek ölçeği"nin ilk altı maddesi duygusal emeğin yüzeysel rol yapma, sonraki dört maddesi derin rol yapma, son üç maddesi ile doğal duygular boyutu ile ilgilidir.

Duygusal emek kavramı Hochschild ile literatüre girmiş olup (Savaş, 2012) bu alandaki çalışmaların henüz yeni olduğu, Türkiye'de ise dış dünyaya bağlı olarak bir hayli yeni olduğu görülmektedir. Aşağıda Türkiye'de duygusal emek üzerine yapılmış çalışmalardan bazıları özetlenmiştir.

Ahmet Cezmi Savaş (2012), "İlköğretim Okulu Müdürlerinin Duygusal Zeka ve Duygusal Emek Yeterliklerinin Öğretmenlerin İş Doyumuna Etkileri” adlı doktora çalışmasında, duygusal zekâ düzeyi yüksek müdürlerin öğretmenlerin iş doyumlarını daha yükseğe çıkaracağını; müdürlerin duygusal zekalarının öğretmenlerin içsel doyum sağlamasında katkısı olacağını; dışsal doyuma ulaşmış öğretmenlerin duygusal zeka düzeyi yüksek müdürlerin bulunduğu okullarda olacağını; mutluluk düzeyi yüksek müdürlerle çalışan öğretmenlerin iş doyumlarının da yüksek olacağını; duygusal emeği yüksek müdürlerin okullarındaki öğretmenlerin iş doyumlarının da yüksek olacağını savunmaktadır.

Kaya (2009), “Özel Okul Öğretmenlerinin Duygusal Emek Davranışlarını Algılama Biçimleri İle İş Doyumları ve İş Stresleri Arasındaki İlişki” adlı yüksek lisans tezinde; kurumların öğretmenlerinden duygularını işlerine olumlu yönde kullanmalarını beklemekte olduklarını; çalışan davranışları ve duygularının memnuniyet olgusu için önemli bir veri olduğu; okulların öğretmenlerden bekledikleri duygusal davranış kuralları konusunda kurumları tarafından bilgilenmekte olduğu; duygusal emek davranışının işin yapılması sırasında gereken bir durum olarak ortaya konulduğuna demografik verilerden bağımsızlık gösterdiğini; özel okul öğretmenlerinin işlerini rol gereklerine göre genel grup halinde uyum göstermeye çalışmakta oldukları bulgularına ulaşmıştır. Araştırmacı, yüksek lisans tezinde, kurumsal yapı olarak eğitim kurumları duygusal emek davranışı kavramını tanımlı olarak kullanmasalar da işin kendisi zaten duygusal emek gerektirmekte olup öğretmenlerin genel olarak bu düşünceye yönelik bir uyum sağlamakta oldukları, duygusal

Toplum Bilimleri Dergisi, Yıl: 15, Sayı: 30, Haziran 2021, s. 231-249 
emek kavramı ile iş doyumu değişkeni arasında ilişki olmakla birlikte nedenselliği açıklayan bir sonuç olduğuna yönelik bulguya ulaştıkları, iş doyumunun işe harcanması gereken duygusal emek değişkenliği ile ilişkisinin olduğunu ve dişsal doyumun duygusal emek ile ilișkisinin daha yüksek olduğunu vurgulamıștır.

Köksel'in (2009) "İş Yaşamında Duygusal Emek ve Ampirik Bir Çalışma" adlı yüksek lisans tezinde, cinsiyet, medeni durum, yaș, mevcut iş yerinde çalışma süresi ve toplam çalışma süresi gibi özelliklere bağlı olarak duygusal emek faktörlerinde herhangi bir değişiklik gözlemlenmediğini; kamu sektöründe çalışanların yüzeysel ve derin rol yapmada boyutlarında özel sektördekilere oranla daha yüksek ortalamalara sahip oldukları; yüzeysel rol yapma davranışın duygusal tükenme ve duyarsızlaşma seviyelerini yükseltmekte olduğunu; iş yerinde sergilenen duygularla hissedilen duygular arasındaki farklılıkların bireylerin iş doyumlarını olumsuz yönde, derin rol yapma davranışları ile ise tükenmişlik arasında güçlü bir bağ kurulamadığını; derinlemesine davranış ile iş doyumu arasında herhangi bir ilişki olduğu yönünde bir tespit olmadığına yönelik bulgulara ulaşmiştır.

Akbıyık (2013), "Etkili Liderliğin Duygusal Emek Davranışları Üzerindeki Etkisi: Hizmet Sektöründe Bir Uygulama" yüksek lisans tezinde, duygusal davranışların kurum açısından önemli olduğu; duygusal emeğin, müşteriyle yüz yüze iletişimin yoğun şekilde sergilendiği hizmet alanında gün geçtikçe daha fazla değer kazanan bir kavram haline gelmekte olduğunu vurgulamıștır.

Begenirbaș ve Meydan'ın (2012), “'Duygusal Emeğin Örgütsel Vatandaşlık Davranışlarıyla İlişkisi: Öğretmenler Üzerine Bir Araştırma" isimli çalışmalarında yüzeysel rol yapan öğretmenlerin örgütsel vatandaşlık davranışı sergilemelerinin daha düşük olduğu; derinden rol yapan öğretmenlerin örgütsel vatandaşlık davranışlarının yüzeysel rol yapanlara nazaran artma eğiliminde olduğu doğal/samimi duygu gösterimlerinin ve buna bağlı doğal davranışların örgütsel vatandaşlık davranışları sergilemelerini pozitif olarak yordadığı; öğretmenin çalışma ortamından memnuniyet duyduğu ve zevk aldığı; duygusal emeğin örgütsel vatandaşlık davranışları (diğerkâmlık, nezaket, vicdanlılık, sivil erdem, centilmenlik) ile anlamlı ilişkisi olduğunu vurgulamışlardır.

Bıyık ve Aydoğan (20149 "Duygusal Emek ile Örgütsel Vatandaşlık Davranışına İlişkin: Bir Araştırma" adlı çalışmalarında, yüzeysel davranış, derinden davranıș ve doğal davranış boyutları ile örgütsel vatandaşlık davranışı arasında pozitif yönde anlamlı düzeyde bir ilişki; derin davranış sergileyen öğretmenlerin örgütsel vatandaşlık davranışı düzeyinin diğer boyutlara göre daha yüksek olduğu; yüzeysel davranış sergileyen öğretmenlerin örgütsel vatandaşlık davranışı düzeyinin diğer boyutlara göre daha düşük olduğu; erkek ögretmenlerin hem de duygusal emek ile örgütsel vatandaşlık davranış düzeyinin kadın öğretmenlerden yüksek olduğu; evli öğretmenlerin duygusal emek ile örgütsel vatandaşlık davranış düzeyinin bekar öğretmenlerden yüksek olduğu; eğitim durumu açısından farklılık olmadığını bulmuşlardır.

Moran ve Çoruk'un (2021) “ilköğretim Kurumlarındaki Öğretmenlerin Duygusal Emek Davranışları ile Yaşam Doyum Düzeyleri Arasındaki İlişsi” adlı çalışmalarında, cinsiyet değişkeninde öğretmenlerin duygusal emek gösterimlerinde anlamlı bir fark olmadığı, yüzeysel rol yapmada anlamlı fark olduğu ve erkeklerin yüzeysel rol yapmada kadınlara göre daha fazla olduğu bulgularına ulaşılmıştır. Bu çalışmada, kıdeme göre de öğretmenlerin duygusal emeklerinde anlamlı bir fark olmadığı, alt boyutlara bakıldığında yüzeysel rol yapmada farklılık olduğu sonuçlarına ulaşıldığı görülmektedir. Yüzeysel rol yapmada anlamlı farkın 21 yıl ve üzeri ile 16-20 yıl arası kıdeme sahip öğretmenler arasındadir.

Polatkan'ın (2016) “Ortaokul Öğretmenlerinin Duygusal Emek Davranışları ile İş Doyumları Arasındaki İlişki" adlı çalışmasında, erkek öğretmenler ile kadın öğretmenlerin yüzeysel rol yapma, derin rol yapma ve doğal duygular boyutlarında cinsiyet değişkenine göre istatiksel açıdan anlamı bir fark olmadığı yönünde sonuçlara ulaştıkları

Toplum Bilimleri Dergisi, Yıl: 15, Sayı: 30, Haziran 2021, s. 231-249 
görülmektedir. Benzer bir şekilde, kıdem değişkeni açsından da öğretmenler arasında, duygusal emek düzeylerinde anlamlı bir fark olmadığını bulmuşlardır.

Duygusal emek ilk önce Hochschild tarafından yüzeysel rol ile derin rol yapma olarak iki boyutu olduğu ifade edilmiş ve daha sonra Ashforth ile Humrey, çalışanların bazen gerçekten hissettikleri gibi davrandıkları için doğal duygular boyutu eklemiş ve duygusal emek böylece üç boyutta ele alınmıştır. Bu çalışmada da bu üç boyut üzerinde değerlendirmede bulunulmuştur.

\subsection{Problem Durumu}

İnsan, doğası gereğince her gün daha farklı olmayı ister. Bu da değişimi ve gelişmeyi zorunlu kılar. İnsan da bu değiş̧ime ve gelişmeye ulaşmak veya uyum sağlamak zorundadır. İnsanı, belli bir plan dahilinde geliştiren ve değiştiren en temel unsur ise okuldur. Okullarda verilen eğitimin kalitesi, donanımlı ve iyi yetiştirilmiş öğretmenler eli ile yürütülmektedir. Nitelikli öğrenci yetiştirebilmek nitelikli eğitim süreci ile mümkündür. Nitelikli eğitim süreci de nitelikli eğitimciler ile mümkündür (Seferoğlu, 2004).

Öğretmenlik, bilgi ve beceri isteyen, bilgi ve becerisini hizmet sunduğu kitleye sunmadaki ilke, metot ve tekniklerin kazanıldığı inanç mesleği olma özelliğini sürdürmektedir. Öğretmenlik, sürekli öğrenmeyi içinde barındıran, bilim ve kültür ile yoğurulmuş, mesleki etik değerleri benimsemiş eğitim iş görenleri arasında kazanılmaktadır. (Yılman, 1992). Öğretmen olmak, öğretmenlik yapmayı aşmaktır. Çünkü öğretmen olmak, öğretmenin, belirlenmiş görevlerinin öresine geçip, hissederek, yaşayarak, kendisini adayarak, öğrenci ile bütünleşerek var olmadır. Öğretmenin öğrencide, öğrencinin öğretmende nüfuz ettiği, sahici ve güçlü bir aidiyettir (Cüceloğlu ve Erdoğan, 2013).

Sosyal bir sistem olarak okul, ilişki ve iletişim ağından oluşmaktadır. En yoğun iletişim ise öğretmen ile öğrenci arasında cereyan etmektedir. Çift yönlü iletişimin niteliği, olumlu olduğunda öğrenme sürecine olumlu, olumsuz olduğunda da öğrenme sürecine olumsuz yansıması kaçınılmazdır. Öğretmen ile öğrenci arasındaki çift yönlü iletişimin gelişmemesi durumunda eğitim hedeflerinden sapmalara neden olacaktır (Habacı ve Çelik, 2013).

Okuldaki en yoğun iletișim, öğretmen ile öğrenci arasındadır. Öğrenme sürecinde, öğretmenin kendisini doğru ifade etmesi önemlidir. Bu süreçte, öğretmenin davranışlarına duyguları yansımaktadır. İnsan, uzun süre duygularını saklaması, bastırması olası değildir. Öğrenciler, öğretmenlerin davranışlarına neden olan duyguları bilmeseler bile hissetmeleri uzun sürmeyecektir.

Öğrenme hedeflerine ulaşmada öğretmen davranışları önem arz etmektedir. Öğretmenin biçimsel davranışların ötesinde katkılar sunmasının öğrenmeye faydalar saylayacağı düşünülmektedir. İletişim yumağı olan okulda, öğretmenler öğrencileri ile iletişimdeyken duygusal emek gösteriminde bulunurlar. Yüz yüze iletişimin olduğu yerde, duygusal emek, kişinin davranışlarında gözlenmesinin yanında kişinin sesine, ses tonuna, jest ve mimiklerine yansımaktadır. Beden diline yansıyan duygusal emek, öğrenci üzerine etkili olacaktır. Hangi öğrenme düzeyinde olursa olsun, öğretmen davranışları öğrenme sürecinde önemlidir. Bu nedenle öğretmenlerin duygusal emek gösterimleri önem arz etmekte olup bu çalışmada ilkokul ve sınıf öğretmenlerinin duygusal emek gösterimleri araştırılmıştır.

\subsection{Araştırmanın Amacı}

Her tür ve seviyedeki öğrenme, öğretim programlarıyla belirlenmiş olup öğretmen davranışlarıyla hayata geçirilmektedir. İnsan davranışlarını duyguları belirlemekte olup öğrenme sürecinde öğretmenin de o gün ki hislerinden bağımsız olarak öğrenmeyi sürdürmesi de olası görülmemektedir. Duygusal emek gösterim düzeylerinin bilinmesi, öğretmenlerin duygularını yönetebilmelerine olanak sağlaması ihtimal dahilindedir.

Toplum Bilimleri Dergisi, Yıl: 15, Sayı: 30, Haziran 2021, s. 231-249 
İlkokul ve lisede görev yapan öğretmenlerin duyusal emek davranışları arasında bir fark olup olmadı̆̆ı, bu araştırmanın amacını oluşturmaktadır. Eğitim alanında, duygusal emek üzerine yürütülen çalışmaların yurt içinde ve yurt dışında sınırlı sayıda olması nedeniyle, bu çalışmanın diğer yeni çalışmaları teşvik etmesi açısından önemli kıldığı düşünülmektedir.

\subsection{Araştırmanın Önemi}

Hochschil'in "Managed Heart" adlı kitabının 1983 yılında yayımlanmasıyla birlikte, araștırmacılar duygusal emek ile tanışmıștır (Yıldırım ve Erul, 2013). Türkiye ise 2000'li yıllarının başında bu kavram ile tanışmıştır. Bu nedenle, ülkemizde farklı sektörlerde duygusal emek çalışmaları başlamış olmakla birlikte henüz çok yenidir. Özelde de eğitim alanında çok az çalışma bulunmaktadır. 2007-2018 Yılları arasında 14 doktora, 48 yüksek lisans seviyesinde çalışma söz konusu olup eğitim bilimlerinde 2 doktora, 2 yüksek lisans çalışması yapıldığı görülmektedir (Savaşkan ve Göktaş Kulualp, 2019).

Okulların çalışma alanı insandır. Bu nedenle okullarda yoğun duygusal emek söz konusudur. Eğitim iş görenin işini yaparken sesinin, jest ve mimiklerinin, vücut diline olumlu yansıması, kişiyi memnun edecek gösterimlerde bulunması, başta öğrenciyi sonrasında veliyi memnun edecektir. Eğitim faaliyetinden direkt veya dolaylı faydalananlar da bu yönde beklenti içindedirler. Sosyal çevre, güler yüz, samimi ilişki, samimiyet, öğrenci sorunları ile ilgilenen ve onlara çözüm bulmak için çabalayan okul çalışanları bekler. İnsanla en fazla muhatap olan mesleklerin başında öğretmenlik mesleği gelir. Öğretmenlerin duygusal emeği bu nedenle önemlidir.

Öğretmenlerin duygusal emeğinin öğrenci, veli ilişkilerinde memnuniyet oluşturacağı, velilerin okula olan güven duygusunu geliştireceği, öğrenci için olumlu ögrrenme ortamları hazırlayacağı öngörülmektedir.

\subsubsection{Problem}

$\mathrm{Bu}$ araştırmada, Çanakkale İli Gelibolu İlçesinde eğitim kademesinin ilkokul bölümünde görev yapan sınıf öğretmenleri ile liselerde görev yapan öğretmenler arasında duygusal emek düzeyleri açısından anlamlı farklılık var mıdır? Sorusuna cevap aranmıștır.

\subsubsection{Alt Problemleri}

1) İlkokul öğretmenleri ile lise öğretmenlerinin duygusal emek düzeyleri arasında anlamlı bir fark var mıdır? midir?

2) İlkokul öğretmenlerinin cinsiyete bağlı olarak duygusal emek düzeyleri farklı midir?

3) İlkokul öğretmenlerinin kıdeme bağlı olarak duygusal emek düzeyleri farklı

4) Lise öğretmenlerin cinsiyete bağlı olarak duygusal emek düzeyleri farklı mıdır?

5) Lise öğretmenlerinin kıdeme bağlı olarak duygusal emek düzeyleri farklı mıdır? Sorularına cevap aranmıştır.

\subsection{Araştırmanın Sınırlılıkları}

Araştırma şu sınırlamalar çerçevesinde yapılmıştır:

1) Gelibolu ilçesindeki ilkokul öğretmenleri ile lise öğretmenlerine uygulanmıştır.

2) Gelibolu ilçesinde bulunan ortaokullar ile halk eğitim merkezleri araştırma dışında tutulmuştur.

3) Gelibolu ilçesinde bulunan ilkokul ve lise öğretmenlerinin ankete samimi cevaplar verdiği varsayılmaktadır. 


\subsection{Yöntem}

$\mathrm{Bu}$ bölümde araştırma modeline, evrene ve örnekleme, araștırma verilerinin toplanmasına ve çözümlemesine ilişkin bulgulara yer verilmiştir.

\subsubsection{Araştırma Modeli}

Araştırma kapsamında Çanakkale İli, Gelibolu ilçesinde görev ilkokul öğretmenleri ile lise öğretmenlerinin duygusal emek gösterimleri ortaya konulmaya çalışılmıştır. İlkokulda görev yapan sınıf öğretmenleri ile lisede görev yapan öğretmenlerin duygusal emek düzeylerini belirlemek amacıyla tarama modeli benimsenmiştir. Geçmiş veya mevcut durumları var olan șekliyle betimleyen tarama modeli, araștırmaya konu olan olay, birey ya da nesne, kendi koşulları içinde ve olduğu gibi tanımlar (Karasar, 2012). Öğretmenlerin duygusal emek gösterimlerinin branş, cinsiyet ve kıdem durumuna göre farklılaşıp farklılaşmadığı incelenmiştir.

\subsubsection{Evren ve Örneklem.}

Araştırmanın evreni Gelibolu ilçesinde görev yapan ilkokul ve lise öğretmenleridir. Araştırma evreni küçük ve ulaşılabilir olduğu için, örneklem alma yoluna gidilmemiş ve evrenin tamamı araştırmaya dahil edilmiştir. İlçede 102 ilkokul, 135 lise öğretmeni görev yaptığından hedeflenen katılımcı sayısı 237 (iki yüz otuz yedi) kişiden oluşmaktadır. Ankete cevap verme yoluyla geri dönenlerin sayısına bakıldığında; 82 sınıf öğretmeni (\%80) ve 120 lise öğretmeni (\%90) olmak üzere 202 anket geri dönmüștür (\%85). Bazı verilerde katılımcılar tarafından kategorik değişkenler belirtilmediği için 12 lise, 5 ilkokul öğretmeninin anketi araştırma dışında tutulmuştur. Sonuç olarak toplamda 185 öğretmenden gelen veriler analize dahil edilmiştir.

\subsubsection{Veri Toplama Aracı}

Yukarıdaki sorulara cevap ararken anket çalışması ile tarama yapılmıştır. Bu araştırma nicel bir araştırma olup tarama modeli ile yapılmıştır. Diefendorf ve arkadaşları (2005) tarafında geliştirilen on dört maddelik ve Türkçe'ye çevrilen "duygusal emek ölçeği"nin Basım ve Begenirbaş (2012) tarafından geçerlik-güvenirliği test edilen, neticesinde on üç maddeye indirilen ölçek kullanılmıștır.

Basım ve Begenirbaş, çalışmalarında birinci örnekleme ait verilerini keşfedici faktör analizine tabi tutmuşlar ve KMO (Kaiser-Mayer-Oklin değerini ,814 olarak bulmuşlardır. Elde edilen değer, ölçeğin geçerli ve güvenilir olduğunda işarettir. Diefendorf ve arkadaşlarının (2005) testinde bulunan ve Türkçe'ye 'Öğrencilerle ilgilenirken sahte duygular gösteririm' şeklinde çevrilen maddenin iki ayrı faktörde birbine çok yakın değerler olduğunu tespit ettikleri için anketten çıkarmışlardır (,412 ve ,442). Birinci örneklemin keşfedici faktör analizinde, ölçeğin toplam varyans analizi 0,67 olarak bulunmuştur. İkinci örnekleme ait veriler, doğrulayıcı faktör analizine tabi tutulmuştur. Veriler her bir model için test edildiğinde değişkenlerin yordama gücü istatistiksel olarak anlamlı olduğunu bulmuşlardır (Basım, Begenirbaş, 2012).

Duygusal Emek Ölçesi iki bölümden meydana gelmekte olup birinci bölümde kategorik değişkenler, ikinci bölümde ise duygusal emeği ölçen ifadeler yer almaktadır. Diefendorff ve arkadaşları tarafından geliştirilen ölçekte 14 madde olup Basım ve Begenirbaş (2012) tarafından Türkçe'ye uyarlandıktan sonra 13 maddeye indirilmiştir. Ölçeğin 1-6'ıncı ifadeleri, yüzeysel rol yapma, 7-10'uncu maddeleri derin rol yapma, 1113'üncü ifadeleri ise doğal duygular alt boyutunu ölçen cümlelerden oluşmaktadır.

Geçerlik-güvenirliği Basım ve Begenirbaş (2012) tarafından test edilen ve Celal Bayar Üniversitesi İ.İ.B.F’nin "Yönetim ve Ekonomi" dergisinde yayımlanan makalede “... ulusal yazında örgütsel ve yönetsel davranış çalışmalarına katkı yapabileceği 
değerlendirilmektedir" (s.88) cümlesi ile yetinilmemiş e-porta yolu ile Basım'dan izin istenmiştir.

Anket soruları beșli Likert ölçeğinden olușmaktadır. Anket sorularında ifade edilen görüşlere katılma dereceleri (1) "hiçbir zaman", (2) "nadiren", (3) "ara sıra", (4) "sık sık", (5) "her zaman” seçeneklerinden oluşturulmuştur.

\subsubsection{Verilerin Analizi}

Araştırmada kullanılan ölçekten elde edilen puanların normal dağılımına yönelik Z puanları tahlil edilmiş olup puanların $-3,+3$ aralığında olması yanında Kolmogorov Smirrnov testi yapılmış, verilerin normal dağılım gösterdiği anlaşılınca parametrik testler uygulanmıştır. Kullanılan ölçekte yer alan faktörlere yönelik yeni puanlar kullanılarak yeniden faktör analizi uygulanmıştır. Kullanılan ölçekte yer alan 13 soru 3 boyutta toplanmış, elde edilen verilere yönelik faktör analizinde de yine 3 boyut çıkmış ve boyutların içinde yer alan sorularda aynı boyutları ölçer nitelikte oluşmuştur. 13 soruya yönelik faktör analizi sonuçları aşağıdaki Tablo 1'de sunulmuştur.

Tablo 1: Duygusal Emek Ölçeği Faktör Analizi Sonuçları

\begin{tabular}{|c|c|c|c|c|}
\hline Boyut & Madde & $\begin{array}{c}\text { 1. Faktör } \\
\text { Yüzeysel } \\
\text { Rol } \\
\text { Yapma } \\
\end{array}$ & $\begin{array}{l}\text { 2. Faktör } \\
\text { Derin Rol } \\
\text { Yapma }\end{array}$ & $\begin{array}{l}\text { 3. Faktör } \\
\text { Doğal } \\
\text { Duygular }\end{array}$ \\
\hline \multirow{6}{*}{ 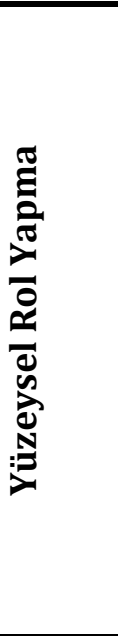 } & Öğrencilerle ilgilenirken iyi & ,824 & 079 &,- 150 \\
\hline & $\begin{array}{l}\text { Öğrencilerle uygun şekilde ilgilenebilmek } \\
\text { için rol yaparım. }\end{array}$ & ,815 & ,029 &,- 077 \\
\hline & $\begin{array}{l}\text { Mesleğimin gerektirdiği duyguları } \\
\text { sergileyebilmek için sanki bir maske } \\
\text { takarım }\end{array}$ & ,813 & 203 &,- 090 \\
\hline & $\begin{array}{l}\text { Mesleğimi yaparken hissetmediğim } \\
\text { duyguları hissediyormuşum gibi } \\
\text { davranırım. }\end{array}$ & ,776 & 273 &,- 064 \\
\hline & $\begin{array}{l}\text { Öğrencilerime, gerçek hissettiğim } \\
\text { duygulardan farklı duygular sergilerim }\end{array}$ & ,669 & ,158 &,- 155 \\
\hline & $\begin{array}{l}\text { Öğrencilerle ilgilenirken bir şov yapar gibi } \\
\text { ekstra performans sergilerim. }\end{array}$ & 640 & ,315 & 077 \\
\hline \multirow{4}{*}{ 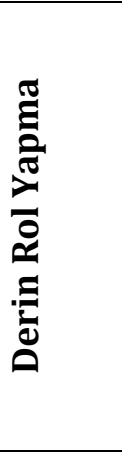 } & $\begin{array}{l}\text { Göstermem gereken duyguları gerçekte de } \\
\text { hissetmek için çaba harcarım. }\end{array}$ & 188 & ,888 &,- 091 \\
\hline & $\begin{array}{l}\text { Öğrencilere göstermem gereken duyguları } \\
\text { hissedebilmek için elimden geleni } \\
\text { yaparım. }\end{array}$ & ,184 & 879 & ,019 \\
\hline & $\begin{array}{l}\text { Öğrencilere sergilemem gereken duyguları } \\
\text { içimde de hissedebilmek için yoğun çaba } \\
\text { gösteririm. }\end{array}$ & 141 & ,819 & 136 \\
\hline & $\begin{array}{l}\text { Öğrencilere göstermek zorunda olduğum } \\
\text { duyguları gerçekten yaşamaya çalışırım. }\end{array}$ & ,215 & ,800 & 019 \\
\hline \multirow{3}{*}{ 音 } & $\begin{array}{l}\text { Öğrencilere gösterdiğim duygular } \\
\text { kendiliğinden ortaya çıkar. }\end{array}$ &,- 075 & ,017 & ,867 \\
\hline & $\begin{array}{l}\text { Öğrencilere sergilediğim duygular } \\
\text { samimidir. }\end{array}$ & 017, & 066, & ,796 \\
\hline & Öğrencilere gösterdiğim duygular o an &,- 294 &,- 013 &, 742 \\
\hline
\end{tabular}


hissettiklerime aynıdır.

Faktör analizi sonucunda 1. Boyut olan "Yüzeysel Rol yapma" boyutunu temsil eden maddenin (madde-2), 2. Boyut olan "Derin Rol Yapma" boyutunu temsil eden maddenin (madde-8), 3. Boyut olan "Doğal Duygular" boyutunu temsil eden maddenin (madde-12) olduğu tespit edilmiştir.

Faktör analizinin ardından her bir faktörün iç tutarlılığına bakılmıștır. 1. Boyut olan "Yüzeysel Rol yapma" boyutunun Cronbach Alpha değeri .873; 2. Boyut olan "Derin Rol Yapma" boyutunun Cronbach Alpha değeri .890; 3. Boyut olan "Doğal Duygular" boyutunun Cronbach Alpha değeri .724 olup, Duygusal Emek ölçeğinin Cronbach Alpha değeri .819 olmuştur.

\subsection{Bulgular ve Yorumlar}

Araştırmaya katılan öğretmenlerin demografik özelliklerine ilişkin frekans analizleri aşağıdaki Tablo 2'de açıklanmaktadır.

Tablo 2: Araştırmaya Katılan Öğretmenlerin Demografik Özellikleri

\begin{tabular}{clrr}
\hline \multicolumn{1}{c}{ Değişken } & Frekans & Yüzde \\
\hline \multirow{4}{*}{ Cinsiyet } & Kadın & 112 & 60,2 \\
& Erkek & 74 & 39,8 \\
& Toplam & 186 & 100,0 \\
\cline { 2 - 4 } Branş̧ İlkokul & 79 & 42,5 \\
& Lise & 107 & 57,5 \\
& Toplam & 186 & 100,0 \\
\cline { 2 - 4 } Kıdem & $1-5$ Yıl & 27 & 14,5 \\
& 6-10 Yıl & 36 & 19,4 \\
& $11-15$ Yll & 30 & 16,1 \\
& $16-20$ Yıl & 44 & 23,7 \\
& $21-25$ Yıl & 26 & 14,0 \\
& 26 Yıl ve üstü & 23 & 12,4 \\
& Toplam & 185 & 100,0 \\
\hline
\end{tabular}

Tablo 2'de görüldüğü üzere araştırmaya katılan öğretmenlerin \%60,2'si kadın, \%39,8'i erkektir. Kadın öğretmen sayısının erkek öğretmenlere kıyasla daha fazla olduğu görülmektedir. Araştırmaya katılan öğretmenlerin \%42,5'i İlkokul, \%57,5'i lisede görev yapmaktadır. Araștırmaya katılan öğretmenlerin \%14,5'i 1-5 Yıl, \%19,4'ü 6-10 yıl, \%16,1'i 11-15 Yıl, \%23,7'si 16/20 yll, \%14'ü 21-25 yll, \%12,4'ünün ise 26 yll ve üstü kıdeme sahip olduğu görülmektedir. Araştırmaya katılan öğretmenlerin büyük çoğunluğunun uzun hizmet süresine sahip olduğu (11 yıl ve üzeri) yani tecrübeli olduğu görülmektedir.

1) İlkokul öğretmenleri ile lise öğretmenlerinin duygusal emek düzeyleri arasında anlamlı bir fark var mıdır?

İlkokulda görev yapan sınıf öğretmenleri ile lisede görev yapan Branş öğretmenlerinin duygusal emek düzeyleri ile ilgili ANOVA (f testi-General Linear Model, Univarte) testi uygulanmak sureti ile elde edilen bulgular, "yüzeysel rol yapma, derin rol yama, doğal duygular" olmak üzere her boyut için ayrı ayrı olmak üzere tablolarda gösterilmiştir. 
Tablo 3: İlkokul Öğretmenleri ile Lisede Öğretmenlerinin "Yüzeysel Rol Yapma" Boyutunda Duygusal Emek Davranışları.

\begin{tabular}{lrrrrr}
\hline & \multicolumn{1}{l}{$\begin{array}{l}\text { Type III } \\
\text { Sum of } \\
\text { Squares }\end{array}$} & df & Square & \multicolumn{1}{c}{ F } & \multicolumn{1}{c}{ Sig. } \\
\hline Source & $8,970^{a}$ & 7 & 1,281 & 1,296 &, 255 \\
Düzleștirilmiş Model & 1,711 & 1 & 1,711 & 1,730 &, 190 \\
Cinsiyet & 1,269 & 1 & 1,269 & 1,283 &, 259 \\
Branş & 6,242 & 5 & 1,248 & 1,262 &, 282 \\
Kidem & 185,000 & 185 & & & \\
Düzeltilmiș Toplam & & & & & \\
\hline
\end{tabular}

Tablo 3'e bakıldığında ilkokulda görev yapan sınıf öğretmenleri ile lisede görev yapan Branş öğretmenlerinin "yüzeysel rol yapma" davranışlarında istatistiksel olarak anlamlı fark görülmemektedir $[(F(1,185)=1,283, p=, 259$ ve $p>0.05)]$.

Araştırma sorumuz, ilkokulda ve lisede görev yapan öğretmenlerin duygusal emek davranışları arasında anlamlı bir farklılık olup olmadığıdır. Tablo 3'e bakıldığında ilkokul ve lise öğretmeni ayırımı olmaksızın cinsiyet açısından "yüzeysel rol yapma" davranışlarında anlamlı fark olmadığı $[(F(1,185)=1,730, p=, 190$ ve $p>0.05)]$, yine ilkokul ve lise ayrımı olmaksızın kıdem açısından bakıldığında da "yüzeysel rol yapma" davranışlarında anlamlı fark olmadığı görülmemektedir $[(F(5,185)=1,262, p=, 282$ ve $\mathrm{p}>0.05)]$.

Tablo 4: İlkokul Öğretmenleri ile Lisede Öğretmenlerinin "Derin Rol Yapma" Boyutunda Duygusal Emek Davranışları.

\begin{tabular}{lrrrrr}
\hline & $\begin{array}{c}\text { Type III Sum of } \\
\text { Squares }\end{array}$ & \multicolumn{4}{c}{ Mean } \\
Source & $17,173^{\mathrm{a}}$ & 7 & 2,453 & 2,602 &, 014 \\
Düzeltilmiş Model & 5,015 & 1 & 5,015 & 5,319 &, 022 \\
Cinsiyet &, 051 & 1 &, 051 &, 054 &, 816 \\
Branş & 7,702 & 5 & 1,540 & 1,634 &, 153 \\
Kıdem & 185,000 & 185 & & & \\
Düzeltilmiș Toplam & &
\end{tabular}

Tablo 4'e bakıldığında ilkokulda görev yapan sınıf öğretmenleri ile lisede görev yapan Branş öğretmenlerinin "derin rol yapma" davranışlarında istatistiksel olarak anlamlı fark görülmemektedir $[(\mathrm{F}(1,185)=, 054, \mathrm{p}=, 816$ ve $\mathrm{p}>0.05)]$.

Araştırma sorusu, ilkokul ve lise öğretmenlerin duygusal emek davranışları arasında anlamlı bir farklılık olup olmadığıdır. Tablo 4'e bakıldığında ilkokul ve lise ayrımı olmaksızın cinsiyet açısından "derin rol yapma" davranışında anlamlı fark olduğu, olduğu $[(\mathrm{F}(1,185)=5,319, \mathrm{p}=, 022$ ve $\mathrm{p}>0.05)]$, erkeklerin $(\mathrm{N}: 74, \bar{x}=3,78, \mathrm{~s} . \mathrm{s}=1,16)$ kadınlara göre (N: $112, \bar{x}=3,10$, s.s= 1,34), erkeklerin (N: 74, $\bar{x}=3,78$, s.s= 1,16) kadınlara göre (N: $112, \bar{x}=3,10$, s.s= 1,34 ) "derin rol yapma" duygusal emek gösteriminin yüksek olduğu bulunmuştur.

İlkokul ve lise ayrımı olmaksızın kıdem açısından bakıldığında "derin rol yapma" davranışlarında anlamlı fark olmadığı görülmemektedir $[(F(5,185)=1,634, p=, 153$ ve $\mathrm{p}>0.05)]$. 
Tablo 5: İlkokul Öğretmenleri ile Lise Öğretmenlerinin “Doğal Duygular” Boyutunda Duygusal Emek Davranışları.

\begin{tabular}{|c|c|c|c|c|c|}
\hline Source & $\begin{array}{c}\text { Type III Sum of } \\
\text { Squares } \\
\end{array}$ & $\mathrm{df}$ & $\begin{array}{c}\text { Mean } \\
\text { Square } \\
\end{array}$ & $\mathrm{F}$ & Sig. \\
\hline Düzeltilmiş Model & $9,396^{a}$ & 7 & 1,342 & 1,361 & ,225 \\
\hline Cinsiyet & ,513 & 1 & ,513 & ,520 & ,472 \\
\hline Branş & 2,787 & 1 & 2,787 & 2,825 & ,095 \\
\hline Kıdem & 5,663 & 5 & 1,133 & 1,148 & 337 \\
\hline Düzeltilmiș Toplam & 185,000 & 185 & & & \\
\hline
\end{tabular}

Tablo 5'e bakıldığında ilkokul ile öğretmenlerinin "doğal duygular" davranışlarında istatistiksel olarak anlamlı fark olmadığı görülmemektedir $[(F \quad(1,185)=$ 2,825, $\mathrm{p}=, 095$ ve $\mathrm{p}>0.05)]$.

Araştırma sorusu, ilkokul ve lisede görev yapan öğretmenlerin duygusal emek davranışları arasında bir fark olup olmadığıdır. Tablo 4'e bakıldığında bakıldığında, ilkokul ve lise ayırımı olmaksızın cinsiyet açısından "doğal duygular" davranışlarında anlamlı fark olmadığı $[(F(1,185)=, 520, p=, 472$ ve p>0.05)], yine Branş ayrımı olmaksızın kıdem açısından bakıldığında "doğal duygular" davranışlarında anlamlı fark olmadığı görülmemektedir $[(F(5,185)=1,148, p=, 337$ ve $p>0.05)]$.

2) İlkokul öğretmenlerinin cinsiyete bağlı olarak duygusal emek düzeyleri farklı midır?

İlkokul öğretmenlerinin cinsiyet açısından duygusal emek düzeyleri ile ilgili Anova (f testi-General Linear Model, Univarte) testi uygulamak suretiyle elde edilen bulgular, "yüzeysel rol yapma, derin rol yapma, doğal duygular" olmak üzere her boyut için ayrı ayrı olmak üzere tablolarda gösterilmiştir.

Tablo 6: İlkokul Öğretmenlerinin Cinsiyet Bağlı "Yüzeysel Rol Yapma" Boyutunda Duygusal Emek Davranışları.

\begin{tabular}{lrrrrr}
\hline & \multicolumn{1}{c}{ Type III Sum of } & \multicolumn{2}{c}{ Mean } \\
Source & \multicolumn{1}{c}{ Squares } & df & Square & \multicolumn{1}{c}{ F } & \multicolumn{1}{c}{ Sig. } \\
\hline Düzeltilmiş Model & $6,008^{\mathrm{a}}$ & 6 & 1,001 &, 902 &, 498 \\
Cinsiyet &, 782 & 1 &, 782 &, 705 &, 404 \\
Error & 79,943 & 72 & 1,110 & & \\
Total & 86,560 & 79 & & & \\
Düzeltilmiș Toplam & 85,951 & 78 & & & \\
\hline
\end{tabular}

Tablo 6'ya bakıldığında ilkokulda görev yapan sınıf öğretmenlerinin cinsiyetlerine göre "yüzeysel rol yapma" boyutunda istatistiksel olarak anlamalı fark görülmemektedir $[(\mathrm{F}(1,78)=, 405, \mathrm{p}=, 404$ ve $\mathrm{p}>0.05)]$.

Tablo 7: İlkokul Öğretmenlerinin Cinsiyete Bağlı “Derin Rol Yapma” Boyutunda Duygusal Emek Davranışları.

\begin{tabular}{lcrrrr}
\hline & $\begin{array}{c}\text { Type III Sum of } \\
\text { Source }\end{array}$ & \multicolumn{4}{c}{ Mean } \\
Squares & df & Square & F & Sig. \\
\hline Düzeltilmiş Model & $14,882^{\text {a }}$ & 6 & 2,480 & 2,655 &, 022
\end{tabular}

Toplum Bilimleri Dergisi, Yll: 15, Sayl: 30, Haziran 2021, s. 231-249 


\begin{tabular}{lrrrrr} 
Cinsiyet &, 361 & 1 &, 361 &, 386 &, 536 \\
Düzeltilmiş Toplam & 82,133 & 78 & & & \\
\hline
\end{tabular}

Tablo 7'ye göre ilkokulda görev yapan sınıf öğretmenlerinin cinsiyetlerine göre "derin rol yapma" boyutunda istatistiksel olarak anlamlı fark görülmemektedir $[(F(1,78)$ $=, 386, \mathrm{p}=, 536$ ve $\mathrm{p}>0.05)]$.

Tablo 8: İlkokul Öğretmenlerinin Cinsiyet Bağlı "Doğal Duygular" Boyutunda Duygusal Emek Davranışları.

\begin{tabular}{|c|c|c|c|c|c|}
\hline Source & $\begin{array}{c}\text { Type III Sum of } \\
\text { Squares }\end{array}$ & $\mathrm{df}$ & $\begin{array}{c}\text { Mean } \\
\text { Square } \\
\end{array}$ & $\mathrm{F}$ & Sig. \\
\hline Düzeltilmiş Model & $4,480^{\mathrm{a}}$ & 6 & ,747 & ,812 &, 564 \\
\hline Cinsiyet & ,866 & 1 & ,866 & 942 & 335 \\
\hline Error & 66,208 & 72 & 920 & & \\
\hline Düzeltilmiș Toplam & 70,688 & 78 & & & \\
\hline
\end{tabular}

Tablo 8'e göre, ilkokul öğretmenlerinin cinsiyetlerine göre "doğal duygular" boyutunda istatistiksel olarak anlamlı fark görülmemektedir $[(F(1,78)=, 942, p=, 335$ ve $\mathrm{p}>0.05)]$.

3) İlkokul öğretmenlerinin kıdeme bağlı olarak duygusal emek düzeyleri farklı midır?

İlkokul öğretmenlerinin cinsiyet açısından duygusal emek düzeyleri ile ilgili Anova (f testi-General Linear Model, Univarte) testi uygulamak suretiyle elde edilen bulgular, "yüzeysel rol yapma, derin rol yapma, doğal duygular" olmak üzere her boyut için ayrı ayrı olmak üzere tablolarda gösterilmiştir.

Tablo 9: İlkokul Öğretmenlerinin Kıdeme Bağlı "Yüzeysel Rol Yapma” Boyutunda Duygusal Emek Davranışları.

\begin{tabular}{|c|c|c|c|c|c|}
\hline Source & $\begin{array}{c}\text { Type III Sum of } \\
\text { Squares }\end{array}$ & $\mathrm{df}$ & $\begin{array}{c}\text { Mean } \\
\text { Square } \\
\end{array}$ & $\mathrm{F}$ & Sig. \\
\hline Düzeltilmiş Model & $6,008^{a}$ & 6 & 1,001 & ,902 & ,498 \\
\hline Kidem & 5,575 & 5 & 1,115 & 1,004 & ,422 \\
\hline Error & 79,943 & 72 & 1,110 & & \\
\hline Total & 86,560 & 79 & & & \\
\hline Düzeltilmiș Toplam & 85,951 & 78 & & & \\
\hline
\end{tabular}

Tablo 9'ya bakıldığında, ilkokul öğretmenlerinin kıdemlerine göre "yüzeysel rol yapma" gösteriminde istatiksel olarak anlamlı fark görülmemektedir $[(F(5,78)=1,004, p$ $=, 422$ ve $\mathrm{p}>0.05)]$. 
Tablo 10: Ilkokul Öğretmenlerinin Kıdeme Göre "Derin Rol Yapma" Boyutunda Duygusal Emek Davranışları.

\begin{tabular}{lrrrrr}
\hline & $\begin{array}{c}\text { Type III Sum of } \\
\text { Source }\end{array}$ & \multicolumn{2}{c}{ Mean } & & \\
\hline Düzeltilmiş Model & $14,882^{\text {a }}$ & 6 & 2,480 & 2,655 &, 022 \\
Kıdem & 12,382 & 5 & 2,476 & 2,651 &, 030 \\
Düzeltilmiş Toplam & 82,133 & 78 & & & \\
\hline
\end{tabular}

Tablo 10'a göre ilkokul öğretmenlerinin duygusal emeğin alt boyutu olan "derin rol yapma" gösteriminde, kıdem açısından bakıldığında anlamlı bir fark olduğu görülmektedir $[(\mathrm{F}(5,78)=2,476, \mathrm{p}=, 030$ ve $\mathrm{p}<0.05)]$.

Kıdem açısından anlamlı farkın, hangi gruplar arasında olduğuna yönelik yapılan istatiksel çözümlemede aşağıdaki sonuçlara ulaşılmıştır.

Tablo 11: İlkokula Öğretmenlerinin Duygusal Emeğinin "Derin Rol Yapma" Boyutunun Kıdem Grupları Arasındaki Farklılı̆̆ı.

\begin{tabular}{|c|c|c|c|c|c|c|}
\hline \multirow[b]{2}{*}{ (I) Kıdem 1} & \multicolumn{3}{|c|}{ Mean } & & \multicolumn{2}{|c|}{ 95\% Confidence Interval } \\
\hline & $\begin{array}{l}\text { (J) Kidem } \\
1 \\
\end{array}$ & $\begin{array}{c}\text { Difference } \\
(\mathrm{I}-\mathrm{J})\end{array}$ & Std. Error & Sig. & $\begin{array}{l}\text { Lower } \\
\text { Bound }\end{array}$ & $\begin{array}{l}\text { Upper } \\
\text { Bound } \\
\end{array}$ \\
\hline \multirow[t]{5}{*}{$11-15$ yll } & $1-5 \mathrm{yll}$ & $-1,1118796$ & 44738573 & ,142 & $-2,4217643$ & 1980050 \\
\hline & 6-10 yıl &,- 6984373 & 33677974 & ,313 & $-1,6844827$ & ,2876080 \\
\hline & $16-20$ yll &,- 7444474 & 34439770 & ,269 & $-1,7527971$ & ,2639023 \\
\hline & $21-25$ yll & $-1,4383910^{*}$ & 38939930 & ,006 & $-2,5784992$ &,- 2982827 \\
\hline & 26 yıl ustu &,- 9775697 & ,41291833 & ,182 & $-2,1865385$ & 2313991 \\
\hline
\end{tabular}

Tablo 11'e bakıldığında 11 - 15 yıl kıdeme $(M=-1,11, S . D=, 45)$ sahip öğretmenler ile 21-25 yıl kıdeme (M=-1,44, S.D=,39) sahip öğretmenler arasında "derin rol yapma" duygusal emek davranışlarında anlamlı bir fark görülmektedir $(\mathrm{p}=, 006, \mathrm{p}<0,50)$.

Tablo 12: Ilkokul Öğretmenlerinin Kıdeme Bağlı "Doğal Duygular" Boyutunda Duygusal Emek Davranışları.

\begin{tabular}{lrrrrr}
\hline & $\begin{array}{c}\text { Type III Sum of } \\
\text { Source }\end{array}$ & \multicolumn{4}{c}{ Mean } \\
Squares & df & Square & \multicolumn{1}{c}{ F } & \multicolumn{1}{c}{ Sig. } \\
\hline Düzeltilmiş Model & $4,480^{a}$ & 6 &, 747 &, 812 &, 564 \\
Kidem & 4,229 & 5 &, 846 &, 920 &, 473 \\
Error & 66,208 & 72 &, 920 & & \\
Düzeltilmiș Toplam & 70,688 & 78 & & & \\
\hline
\end{tabular}

Tablo 12'ye göre, ilkokul öğretmenlerinin kıdemlerine göre "doğal duygular" davranışlarında istatistiksel olarak anlamlı fark görülmemektedir $[(F(5,78)=, 920, p=$ ,473 ve $\mathrm{p}>0.05)]$. 


\section{4) Lise öğretmenlerinin cinsiye bağlı olarak duygusal emek düzeyleri farklı midır?}

Lise öğretmenlerinin cinsiyet açısından duygusal emek düzeyleri ile ilgili Anova (f testi-General Linear Model, Univarte) testi uygulamak suretiyle elde edilen bulgular, "yüzeysel rol yapma, derin rol yapma, doğal duygular" olmak üzere her boyut için ayrı ayrı olmak üzere tablolarda gösterilmiştir.

Tablo 13: Lise Öğretmenlerinin Cinsiyet Bağlı "Yüzeysel Rol Yapma” Boyutunda Duygusal Emek Davranışları.

\begin{tabular}{lrrrrr}
\hline & \multicolumn{2}{c}{ Type III Sum of } & \multicolumn{2}{c}{ Mean } \\
Source & \multicolumn{1}{c}{ Squares } & df & Square & \multicolumn{1}{c}{ F } & \multicolumn{1}{c}{ Sig. } \\
\hline Düzeltilmiş Model & $4,281^{\text {a }}$ & 6 &, 713 &, 761 &, 602 \\
Cinsiyet &, 949 & 1 &, 949 & 1,013 &, 317 \\
Düzeltilmiș Toplam & 97,990 & 106 & & & \\
\hline
\end{tabular}

Tablo 13'e göre, lise öğretmenlerinin cinsiyetlerine göre "yüzeysel rol yapma" boyutunda istatiksel olarak anlamlı fark görülmemektedir $[(F(1,106)=, 949, p=, 317$ ve $\mathrm{p}>0.05)]$.

Tablo 14: Lise Öğretmenlerinin Cinsiyet Bağlı "Derin Rol" Boyutunda Duygusal Emek Davranişları.

\begin{tabular}{lrrrrr}
\hline & \multicolumn{1}{c}{ Type III Sum of } & \multicolumn{2}{c}{ Mean } \\
Source & Squares & df & Square & \multicolumn{1}{c}{ F } & \multicolumn{1}{c}{ Sig. } \\
\hline Düzeltilmiş Model & $13,008^{\text {a }}$ & 6 & 2,168 & 2,464 &, 029 \\
Cinsiyet & 4,512 & 1 & 4,512 & 5,127 &, 026 \\
Düzeltilmiş Toplam & 101,013 & 106 & & & \\
\hline
\end{tabular}

Tablo 14'e bakıldığında, lise öğretmenlerinin cinsiyetlerine göre "derin rol yapma" davranışlarında istatiksel olarak anlamlı fark görülmektedir $[(\mathrm{F}(1,106)=4,512, \mathrm{p}=, 026$ ve $\mathrm{p}<0.05)]$. Derin rol yapma boyutunda erkek öğretmenlerin ortalamalarının $(\mathrm{N}: 56, \bar{x}=$ $3,95$, s.s= 1,086$)$ kadın öğretmenlerden $(\mathrm{N}: 51, \bar{x}=3,51$, s.s= 1,255$)$ yüksek olduğu bulunmuştur.

Tablo 15: Lise Öğretmenlerinin Cinsiyete Bağlı "Doğal Duygular" Boyutunda Duygusal Emek Davranışları.

\begin{tabular}{|c|c|c|c|c|c|}
\hline Source & $\begin{array}{c}\text { Type III Sum of } \\
\text { Squares } \\
\end{array}$ & $\mathrm{df}$ & $\begin{array}{c}\text { Mean } \\
\text { Square } \\
\end{array}$ & $\mathrm{F}$ & Sig. \\
\hline Düzeltilmiş Model & $4,441^{\mathrm{a}}$ & 6 & ,740 & 697 & ,652 \\
\hline Cinsiyet & 160 & 1 & 160 & 151 & 698 \\
\hline Düzeltilmiș Toplam & 110,605 & 106 & & & \\
\hline
\end{tabular}

Tablo 15’e bakıldığında, lise öğretmenlerinin cinsiyetlerine göre "doğal duygular" davranışlarında istatiksel olarak anlamlı fark görülmektedir $[(F(1,106)=, 151, p=, 698$ ve $\mathrm{p}>0.05)]$. 


\section{5) Lise öğretmenlerinin kıdeme bağlı olarak duygusal emek düzeyleri farklı midır?}

Lise öğretmenlerinin cinsiyet açısından duygusal emek düzeyleri ile ilgili Anova (f testi-General Linear Model, Univarte) testi uygulamak suretiyle elde edilen bulgular, "yüzeysel rol yapma, derin rol yapma, doğal duygular" olmak üzere her boyut için ayrı ayrı olmak üzere tablolarda gösterilmiştir

Tablo 16: Lise Öğretmenlerinin Kıdeme Bağlı "Yüzeysel Rol Yapma” Boyutunda Duygusal Emek Davranışları.

\begin{tabular}{lrrrrr}
\hline & \multicolumn{1}{c}{ Type III Sum of } & \multicolumn{2}{c}{ Mean } \\
Source & Squares & df & Square & \multicolumn{1}{c}{ F } & Sig. \\
\hline Düzeltilmiş Model & $4,281^{\text {a }}$ & 6 &, 713 &, 761 &, 602 \\
Kıdem & 3,031 & 5 &, 606 &, 647 &, 664 \\
Düzeltilmiș Toplam & 97,990 & 106 & & & \\
\hline
\end{tabular}

Tablo 16'ya bakıldığında, lise öğretmenlerinin kıdemlerine göre "yüzeysel rol yapma" davranışlarında istatiksel olarak anlamlı fark olmadığı görülmektedir $[(F(5,106)$ $=, 606, \mathrm{p}=, 664$ ve $\mathrm{p}>0.05)]$.

Tablo 17: Lise Öğretmenlerinin Kıdeme Bağlı "Derin Rol Yapma” Boyutunda Duygusal Emek Davranışları.

\begin{tabular}{lrrrrr}
\hline & \multicolumn{1}{c}{ Type III Sum of } & \multicolumn{2}{c}{ Mean } \\
Source & Squares & df & Square & \multicolumn{1}{c}{ F } & Sig. \\
\hline Düzeltilmiș Model & $13,008^{a}$ & 6 & 2,168 & 2,464 &, 029 \\
Kıdem & 7,889 & 5 & 1,578 & 1,793 &, 121 \\
Düzeltilmiș Toplam & 101,013 & 106 & & & \\
\hline
\end{tabular}

Tablo 11'e bakıldığında, lise öğretmenlerinin kıdeme göre "derin rol yapma" boyutunda istatiksel olarak anlamlı fark olmadığı görülmektedir $[(F(5,106)=1,578, p=$ ,121 ve $\mathrm{p}>0.05)]$.

Tablo 18: Lise Öğretmenlerinin Kıdeme Göre “Doğal Duygular" Boyutunda Duygusal Emek Davranışları.

\begin{tabular}{lrrrrr}
\hline & \multicolumn{1}{c}{ Type III Sum of } & \multicolumn{2}{c}{ Mean } \\
Source & Squares & df & Square & \multicolumn{1}{c}{ F } & \multicolumn{1}{c}{ Sig. } \\
\hline Düzeltilmiş Model & $4,441^{\text {a }}$ & 6 &, 740 &, 697 &, 652 \\
Kıdem & 4,415 & 5 &, 883 &, 832 &, 530 \\
Düzeltilmiș Toplam & 110,605 & 106 & & & \\
\hline
\end{tabular}

Tablo 18'e bakıldığında, lise öğretmenlerinin kıdeme göre "derin duygular" davranışlarında istatiksel olarak anlamlı fark olmadığı görülmektedir $[(F(5,106)=, 832, p$ $=, 530$ ve $\mathrm{p}>0.05)]$. 


\section{SONUÇ VE ÖNERÍLER}

İster yüz yüze ister herhangi bir iletişim aracılığıyla olsun hizmet sunan kişinin, hizmeti alan kiși ile iletişimi ve kișiye yönelik davranışları, kurumsal memnuniyetin belirlenmesinde önemli bir özelliğe sahiptir. Okullar da hizmet örgütleri içerisinde ilişki ağının ve niteliğinin önem arz ettiği kurumlardır. Eğitim örgütlerinde yoğun ilişki yaşanmakta olup bu ilişkilerin pozitif olması halinde hizmet kalitesi, öğrenci ve veli memnuniyeti artacağı da açıktır. Bu nedenle okullardaki öğretmenlerin ister öğrenciye yönelik, ister öğrenci velisine yönelik duygusal emek davranışları, bu nedenle önemlidir.

$\mathrm{Bu}$ çalışmada, ilkokul ile lise öğretmenlerinin duygusal emeğin "yüzeysel rol yapma, doğal rol yapma ve doğal duygular" alt boyutlarında anlamlı bir fark olmadığı görülmektedir.

İlkokul ve lise öğretmenlerinin "cinsiyet-kıdem" açısından duygusal emeğin "yüzeysel rol yapmada" ile "derin duygular" boyutlarında cinsiyet ve kıdem değişkenine göre istatiksel anlamda, anlamlı bir fark olmadığı görülmüştür. Begenirbaş ve Meydan (2012), Bıyık ve Aydoğan'ın (2014) araştırmalarına bakıldığında cinsiyet açısından "yüzeysel rol yapma" duygusal emek davranışlarında fark olmadığı görülmekte olup yaptığımız çalışma sonuçları ile benzerlik arz etmektedir. Polatkan'ın (2016) çalışmasında, ortaokul öğretmenlerinin yüzeysel rol yapma, derin rol yapma ve doğal duygular boyutunda cinsiyet ev kıdem değişkenleri açısından istatistiksel açıdan anlamlı fark olmadığı bulgusu araştırmamız ile benzerlik azr etmektedir.

Bununla birlikte, ilkokul ve lise öğretmeni ayrımı olmaksızın, duygusal emeğin "derin rol yapma" davranış boyutunda cinsiyet açısından, istatiksel olarak anlamlı fark olduğu görülmektedir. Farka bakıldığında erkek öğretmenlerin derin rol yapma alt boyutundaki duygusal emek davranışlarının, kadın öğretmenlerden yüksek olduğu görülmektedir. Türkiye'de yapılan diğer çalışmalarda da benzer sonuçlara ulaşılmıştır (Bıyık ve Aydoğan, 2014; Çoruk, 2014).

İlkokul öğretmenleri kendi içinde cinsiyet ve kıdem ile lise öğretmenleri kendi içinde cinsiyet ve kıdem değişkeni açısından sonuçlara bakıldığında;

İlkokul öğretmenlerinin, cinsiyet açısından "yüzeysel rol yapma”, "derin rol yapma" ve "doğal duygular" davranış boyutlarında istatiksel anlamda bir fark olmadığı görülmekte olup "yüzeysel rol yapma" ile "doğal duygular" açısından diğer çalışmalar ile benzerlik arz etmesine rağmen "derin rol yapma" açısından ise benzerlik arz etmediği görülmektedir (Begenirbaş ve Meydan, 2012; Bıyık ve Aydoğan, 2014; Çoruk, 2012). Moran ve Çoruk'un (2021) yaptı̆̆ çalışmada, ilkokuldaki erkek öğretmenlerin kadın öğretmenler daha fazla yüzeysel rol yapma davranışı gösterdiği bulgusu ile örtüşmemektedir.

Ancak, ilkokul öğretmenlerinin duygusal emeğin "derin rol yapma" davranışında 21 - 25 yıl kıdeme sahip olan öğretmenler ile 11 - 15 yıl kıdeme sahip öğretmenler arasında istatiksel anlamda fark olduğu bulgusuna ulaşılmıştır. 21 - 25 yıl kıdeme sahip sınıf öğretmenlerinin "derin rol yapma" duygusal emek davranışlar ortalamalarının 11 15 yıl kıdeme sahip sınıf öğretmenlerinin "derin rol yapma" duygusal emek davranışlarından yüksek olduğu görülmektedir. Kıdem, yaş ile birlikte gelmekte olup beraberinde kişiye tecrübe kazandırmaktadır. Yaş ve kıdem artışının duygusal emek davranışına olumlu katkı sağladığı görülmekte olup yaş arttıkça duygu kontrolünün arttığı diğer çalışmalarda da bulunmuş bir sonuç olup araştırmamızla benzerlik arz etmektedir (Bıyık ve Aydoğan, 2014; Çoruk, 2012; Moran ve Çoruk, 2021).

Lisede öğretmenlerinin "yüzeysel rol yapma, derin davranış ve doğal duygular" duygusal emek davranışlarına bakıldığında, yüzeysel rol yapma ve doğal duygular boyutlarında cinsiyet ve kıdeme bağlı bir farklılık olmadığı; derin rol yapma boyutunda ise kıdeme bağlı herhangi bir farklılık olmadığı, ancak cinsiyete bağlı farklılık olduğu, erkeklerin derin rol yapma davranış ortalamalarının kadınlara göre yüksek olduğu 
bulunmuştur. Bu bulgu, Türkiye'de yapılan diğer araştırma sonuçları ile benzerlik arz etmektedir (Begenirbaş ve Meydan, 2012; Bıyık ve Aydoğan, 2014; Çoruk, 2012).

Genelde, kadınların daha duygusal oldukları, bu nedenle duygusal emek davranışlarının erkeklere göre daha yüksek çıkması beklenirken, bunun tam tersi bir durum söz konusudur. "Hochschild, iş yaşamında hemen herkesin duygusal emek gösterdiğini ancak bunun çoğunun kadınlardan beklendiğini ifade etmiştir" (Çoruk, 2012). Hochschild'in bu tespiti bizim çalışmamızda ulaştığımız bulguyla çeliştiği gibi Akbıyık (2013), Bıyık ve Aydığan (2014), Basık ve Begenirbaş (2012), Çoruk (2012) gibi yazarların bulguları ile çeliştiği görülmektedir.

Duygusal emek ile ilgili çalışmalar dünyada yeni olduğu gibi ülkemizde ise çok daha yenidir ve eğitim sektöründe yapılan çalışmalar de bir hayli sınırlıdır. Eğitim, hizmet sektörleri arasında yer almakta olup duygusal emek ile ilgili farklı değișkenlerle, farklı öğretim kademelerinde araştırmalar yapılmalıdır. Evli-bekar, eğitim düzeyi gibi değişkenlerin duygusal emek üzerine etkileri araştırılabilir.

Hochschild'in (2003), kadınların ereklere göre daha fazla duygusal emek gösteriminde bulunduğunda yönelik bulgusu söz konusudur. Ülkemizde yapılan sınırlı sayıda yapılan araştırmalarda, derin rol yapmada erkek öğretmenlerin kadın öğretmenlere göre daha fazla duygusal emek gösteriminde bulundukları sonuçları söz konusudur. Bu farklılığın nelerden kaynaklandığında yönelik çalışmalar yapılabilir. 


\section{KAYNAKÇA}

Akbıyık, Melis. Etkili Liderliğin Duygusal Emek Davranışları Üzerindeki Etkisi: Hizmet Sektöründe Bir Uygulama Yüksek Lisans Tezi. Ege Üniversitesi, Sosyal Bilimler Enstitüsü, Halkla İlişkiler ve Tanıtım Anabilim Dalı, Kişiler Arası İletişim Yüksek Lisans Programı, 2013.

Aydoğan, Enver ve Yunus Bıyık. Duygusal Emek ile Örgütsel Vatandaşlık Davranışı İlişsisi: Bir Araștırma. Gazi Üniversitesi İktisadi ve İdari Bilimler Fakültesi Dergisi, 16/3 (2014); 159-180.

Basım, Nejat ve Memduh Begenirbaş. Çalışma Yaşamında Duygusal Emek: Bir Ölçek Uyarlama Çalışması. Yönetim ve Ekonomi: Celal Bayar Üniversitesi, İktisadi ve İdari Bilimler Fakültesi Dergisi, Yönetim ve Ekonomi, 19/1 (2012): 77-90.

Begenirbas, Memduh ve Cem Harun Meydann. Duygusal Emeğin Örgütsel Vatandaşlık Davranışıyla İlişkisi: Öğretmenler Üzerine Bir Araştırma. Gazi Üniversitesi İktisadi ve İdari Bilimler Fakültesi Dergisi, 14/3 (2012): 159-181.

Cüceloğlu, Doğan ve İrfan Erdoğan. Öğretmen Olmak Bir Cana Dokunmaktır. İstanbul: Final Kültür Yayınları, 1. Baskı, İstanbul: 2013.

Çoruk, Adil. Yükseköğretim Kurumlarında Görev Yapan İdari Personelin Duygusal Emek Davranışları. Ondokuz Mayıs Üniversitesi Eğitim Fakültesi Dergisi. 33/1 (2014): 7993.

Çukur, Cem Şafak. Öğretmenlerde Duygusal İşçilik Ölçeği Geliştirme: Geçerlik ve Güvenirlik Çalışması. Kuram ve Uygulamada Eğitim Bilimleri, 9/2 (2009): 527-574.

Diefendorff, James M., Crolye MH ve RH Grosserand. The Dimensionality and Antecedents of Emotinal Labor Strategies. Journal of Vocational Behavior, 6/20 (2005): 339-357.

Grandey, Arlie. The Effects of Emotional Labor: Employee Attitudes, Stress and Performance, Yayımlanmamış Doktora Tezi, Colorado State University, Colorado, 1999.

Habacl, İbrahim ve Ezgin Çelik. Effective communication in educational administration. USChina Education Review, 3/9 (2013): 690-702.

Hochschild, Arlie Russel. The Managed Heart: The Commercialization of Human Feeling. University of California Press, Berkeley and Los Angeles: 2003.

Karasar, Niyazi. Bilimsel Araştırma Yöntemi. Ankara: Nobel Yayınevi, 2012.

Kaya, Erdem. Özel Okul Öğretmenlerinin Duygusal Emek Davranışlarını Algılama Biçimleri İle İş Doyumları ve Isş Stresleri Arasındaki İlişki Yüksek Lisans Tezi. Marmara Üniversitesi, Sosyal Bilimler Enstitüsü, Endüstri ve Örgütsel Psikoloji Anabilim Dalı, 2009.

Köksel, Lale. İş Yaşamında Duygusal Emek ve Ampirik Bir Çalışma Yüksek Lisans Tezi. Celal Bayar Üniversitesi, Sosyal Bilimler Enstitüsü İşletme Anabilim Dalı, Yönetim ve Organizasyon Programı, 2009.

Moran, Cem, Adil ÇORUK. İlköğretim Kurumlarındaki Öğretmenlerin Duygusal Emek Davranışları ile Yaşam Doyumu Düzeyleri Arasındaki İlişki. Trakya Eğitim Dergisi. 11/1 (2021): 267-284. doi: 10.24315/tred.705878

Öz, Ela ÜNLER. Duygusal Emek Davranışlarının İş Sonuçlarına Etkisi (Effect of Emotional Labor On Employees" Work Outcomes Doktora Tezi). Beta Yayıncllık, İstanbul, 2007.

Özgen, Işıl. Turizm Işsletmelerinde Duygusal Emek. Ankara: Detay Yayıncllık, 2010. 
Savaş, Ahmet Cezmi. İlköğretim Okul Müdürlerinin Duygusal Zeka ve Duygusal Emek Yeterliklerinin Öğretmenlerin İş Doyumuna Etkisi Doktora Tezi. Gaziantep Üniversitesi, Sosyal Bilimler Enstitüsü, Eğitim Bilimleri Enstitüsü Anabilim Dalı, 2012.

Savaşkan, Yağmur ve Halime Göktaş Kulualp. Duygusal Emek Konusunu Araştıran Lisansüstü Tezlere Yönelik Bir İçerik Analizi. Elektronik Sosyal Bilimler Dergisi, 18/70 (2019): 818-837.

Seferoğlu, Süleyman Sadi. "Öğretmen Yeterlikleri ve Mesleki Gelişim”. Bilim ve Aklın Aydınlı̆̆ında Ĕ̆itim, 58 (2004): 40-45.

Polatkan, Nahide Nur. Ortaokul Öğretmenlerinin Duygusal Emek Davranışları İle Isş Doyumları Arasındaki İlişki Yüksek Lisans Tezi. Adnan Menderes Üniversitesi, Sosyal Bilimler Enstitüsü, Eğitim Yönetimi Teftiş, Planlaması ve Ekonomisi Anabilim Dalı, 2016.

Yıldırım, Mehmet Halit ve Emel Eylül Erul. Duygusal Emek Davranışının İsgörenlerin Tükenmişlik Düzeylerine Etkisi. Organizasyon Ve Yönetim Bilimleri Dergisi, 5/1 (2013): 89-99.

Yılman, Mustafa. Öğretmenlik Mesleği ve Meseleleri. Türkiye Milli Kültür Vakfı Yayınları, Bayrak Yayıncılık ve Matbaacılık, İstanbul, 1992. 